\title{
ЛОГІКА ВИЗНАЧЕННЯ ЗДОРОВ'Я ІНДИВІДА ТА ПОПУЛЯЦІї. ЧАСТИНА 1. КОНЦЕПТУАЛІЗАЦІЯ
}

\author{
О. П. Мінцер, О. В. Палагін ${ }^{1}$, А. М. Новик ${ }^{2}$ \\ Національний університет охорони здоров'я України імені П. Л. Шупика \\ ${ }^{1}$ /нститут кібернетики імені В. М. Глушкова НАН України \\ ${ }^{2} \mathrm{TOB} « H B K$ «Екофрарм»»»
}

\begin{abstract}
Розглядається здоров'я людини як результат фрункціонування складної саморегулюючої системи, її емерджентні властивості. Аналізуються проблеми кількісного оцінювання здоров'я на основі прямих і непрямих методів дослідження, комплексних, багатокритеріальних і інтегральних оцінок. Обговорюються методологічні аспекти оброблення даних про здоров'я людини, методи згортання показників, індикатори стану пацієнта. Запропоновано нове визначення здоров'я, підхід до розроблення моделей-класифрікацій станів здоров'я пацієнтів і популяції, можливості оцінювання здоров'я на основі сукупності репрезентативних параметрів із урахуванням неповних і неточних знань про їх важливість та пріоритетність такого оцінювання.
\end{abstract}

Ключові слова: здоров'я індивіда та популяції, дефрініції здоров'я, моделі-класифікації, інтегральні оцінки здоров'я, вартісно-орієнтована медична допомога, інформаційні технології, нова фрілософія індивідуального здоров'я, комплексне спостереження за станом здоров'я, індикатори оцінювання індивідуального здоров'я, технічні засоби моніторингу особистого здоров'я.

\section{THE LOGIC OF THE INDIVIDUAL AND POPULATION HEALTH DETERMINING. PART 1. CONCEPTUALIZATION}

\author{
O. P. Mintser, O. V. Palagin ${ }^{1}$, A. M. Novyk ${ }^{2}$ \\ Shupyk National Healthcare University of Ukraine \\ ${ }^{1}$ V. M. Glushkov Institute of Cybernetics of the National Academy of Sciences of Ukraine \\ ${ }^{2}$ Research and Production Company Ecopharm, Ltd.
}

Background. Healthcare systems around the world are characterized by constant and high costs, inadequate costs and patient outcomes. A number of countries, in particular the United States, are moving to a value-oriented model. Accordingly, there is the problem of a new definition of health. However, such a definition cannot be formulated without a proper understanding of what "health" really means. The goal of the work is to generalize approaches to the definition and measurement of individual and population health.

Materials and methods. Results. Human health is considered as a result of the functioning of a complex self-regulating system, its emergent properties. Problems of quantitative health assessment are analyzed on the basis of direct and indirect research methods, complex, multicriteria and integrated assessments. Methodological aspects of data processing on human health are discussed, methods of convolution of indicators, indicators of the patient's condition.

Conclusions. The identification, assessment and management of personal health should be seen today as the most important social issues that need to be addressed immediately. A new concept of definition and assessment of individual and population health is proposed. A new definition of health is proposed, an approach to the development of models-classifications of health conditions of patients and populations, the possibility of health assessment with a set of representative parameters, taking into account incomplete and inaccurate knowledge about their importance and priority of assessment. For the processes of medical rehabilitation, the proposed concept provides a quantitative tool for a loyal assessment of the correctness of the chosen path to recovery.

Key words: health of the individual and population, definitions of health, classification models, integrated health assessments, cost-oriented medical care, information technology, a new philosophy of individual health, comprehensive monitoring of health, indicators in the assessment of individual health, technical means of monitoring personal health. 


\title{
ЛОГИКА ОПРЕДЕЛЕНИЯ ЗДОРОВЬЯ ИНДИВИДА И ПОПУЛЯЦИИ. ЧАСТЬ 1. КОНЦЕПТУАЛИЗАЦИЯ
}

\author{
О. П. Минцер, А. В. Палагин ${ }^{1}$, А. М. Новик ${ }^{2}$ \\ Национальный университет здравоохранения Украины имени П. Л. Шупика \\ ${ }^{1}$ Институт кибернетики имени В. М. Глушкова НАН Украины \\ ${ }^{2} \mathrm{OOO} \ll Н П К ~ « Э к о ф р а р м » » »$
}

\begin{abstract}
Рассматривается здоровье как результат фрункционирования сложной саморегулирующейся системы, её эмерджентные свойства. Анализируются проблемы количественного оценивания здоровья на основе прямых и косвенных методов исследования, комплексных, многокритериальных и интегральных оценок. Обсуждаются методологические аспекты обработки данных относительно здоровья человека, методы свертывания показателей, индикаторы состояния пациента. Предложено новое определение здоровья и оригинальный подход к разработке моделей-классификации состояний здоровья пациентов и популяции. Определены возможности оценки здоровья при помощи совокупности репрезентативных параметров с учетом неполных и неточных знаний об их важности и приоритетности такого оценивания.
\end{abstract}

Ключевые слова: здоровье индивида и популяции, дефиниции здоровья, модели-классификации, интегральные оценки здоровья, ценностно-ориентированная медицинская помощь, информационные технологии, новая филососрия индивидуального здоровья, комплексное наблюдение за состоянием здоровья, индикаторы в оценке индивидуального здоровья, технические средства мониторинга личного здоровья.

Вступ. Системи охорони здоров’я в усьому світі характеризуються постійними та високими витратами, неадекватиними витратами та результатами лікування пацієнтів. Ряд країн, зокрема, США переходять до ціннісно-орієнтованої моделі. Відповідно виникає проблема нового визначення здоров'я. Проте, визначення неможливо сформулювати без належного розуміння того, що насправді означає «здоров'я». Спочатку, щоб по-справжньому зрозуміти його значення з наукової точки зору, вважаємо за необхідне дати історичне розуміння змін у концепції здоров'я та ї̈ еволюціонування. Але окрім соціального та наукового визначення особливий інтерес становить логіка оцінювання особистого здоров' я. Акцентований інтерес до проблеми збереження здоров'я виявляється як із боку кожної людини, так і з боку закладів профілактичної медицини, державних установ, компаній, що виробляють різні пристрої, лікарські засоби тощо. Але досить важко знайти відповідь, що ж саме ми зберігаємо й як виміряти ефект наших зусиль.

Стаття складається з трьох частин: концептуалізація, системні питання вимірів індивідуального здоров'я, проблеми обгрунтування взаємодії здоров’я індивіда з навколишнім середовищем (питання дем- та сінекології).

Мета роботи: узагальнити підходи до визначення та виміру індивідуального та популяційного здоров'я.

Результати та їх обговорення. Дослідження поняття «здоров'я» не припиняються протягом сторічь. Визначення здоров'я еволюціонувало багато разів, часто відображаючи конкретні рівні наукового та медичного розуміння. Але до теперішнього часу проблема визначення здоров'я вельми далека від оптимального рішення. Широке впровадження інформатики забезпечило контекст для нового концептуального бачення, що потрібно в сучасну епоху. Розглянемо традиційні та нові погляди на поняття здоров'я.

Традиційні дефініції здоров'я. Оксфордський онлайн-словник (2016) визначає здоров’я як: «стан буття, вільний від хвороби або травми». Так само онлайн-словник Merriam-Webster (2016) визначає здоров’я просто як: «стан здоров’я або відсутність хвороб, тобто стан здоров'я тіла, розуму або духу; особливо свобода від фізичних хвороб або болю». Хоча кожен $з$ цих визначень має свої переваги, їх сфера застосування обмежена.

В дійсності, еволюцію змінення контексту здоров’я слід розпочати з визначення Гіппократа, відповідно до якого здоров'я є стан тілесної рівноваги, що може бути досягнуте за допомогою поведінкових і лікарських дій. У той час як деякі східні медичні практики все ще зберігають елементи духовності в медицині, всі сучасні медичні практики в розвиненому світі, включаючи східну медицину, покладаються на гіппократівську концепцію здоров’я як продукту екологічних і поведінкових факторів.

Дефініція Всесвітньої організації охорони здоров’я (ВООЗ), висловлена ще в 1948 році, така: «Здоров'я - стан повного фізичного, психічного та соціального благополуччя, а не тільки 
відсутність хвороб» [51]. Нове визначення здоров’я ВООЗ справило величезний соціальний вплив, оскільки кинуло виклик політичним, академічним, громадським і професійним організаціям, вимагаючи виділення ресурсів для досягнення високої мети загального благополуччя. Через свою розширену сферу застосування воно вважалося позитивним кроком уперед у сприйнятті та досягненні здоров’я. При всій історичній важливості даного визначення, що вперше підкреслило категорію здоров'я як новий концепт, проте лише частково пов'язано з відсутністю хвороби, воно не тільки не містить метричну складову, але й не визначає взаємозв'язок людини та навколишнього середовища, не акцентує увагу на важливості ресурсів здоров'я. Частина критичних зауважень зосереджена на слові «повного», що багато хто вважає абсолютним і важко піддається вимірюванню. Крім того, виникають питання про можливість взагалі існування людини без будь-яких фізичних або розумових, або соціальних проблем. Проте, навіть при такому сприйнятті визначення здоров’я, воно залишається примарним із точки зору його реалізації. Як приклад недосяжності його мети часто наводять цілі розвитку тисячоліття, сформульовані Організацією Об'єднаних Націй для світової спільноти, що повинні бути досягнуті до 2015 року, та які включали глобальні ініціативи в галузі охорони здоров'я, проте не були виконані в установлені строки [59, 60].

У зв'язку з глобальною кризою охорони здоров'я J. Bircher, експерт з економіки охорони здоров'я, запропонував змінити визначення здоров'я на таке: «динамічний стан благополуччя, що характеризується фізичним, психічним і соціальним потенціалом індивіда для задоволення потреб життя, властивих тільки його віку, культурі й особистій відповідальності» [26]. Але в епоху, коли економічні міркування є ключовим компонентом диспропорцій в охороні здоров'я, а вартісноорієнтована охорона здоров'я стає нормою, застосування такого визначення може спричинити ще більші диспропорції та завести доволі далеко. А от твердження, що здоров'я не статично, а динамічно, дійсно, характеризує здатність людського організму «до адаптації і самоуправління». Ця концепція розглядає здоров'я як динамічний процес і ресурс для повсякденного життя. Отже, щоб бути здоровим, людині необхідна здатність підтримувати гомеостаз і відновлюватися після навантажень. Ця здатність відома як життєстійкість.

У іншому дослідженні пропонується перевизначити здоров’я як «задовільний і прийнятний стан фізичного (біологічного), психічного (інтелектуального), емоційного (психологічного), економічного (фінансового) та соціального (громадського) благополуччя [23]. В цій же роботі J. Bircher iз співавторами запропонував нову ідею визначення здоров'я людини, що базується на моделі Мейкірха. Модель випливає з парадигми системи охорони здоров'я та являється новою концептуальною основою для нашого розуміння здоров'я і хвороби. Вважається, що нове бачення необхідно для стійкості та більшої ефективності систем охорони здоров'я. J. Bircher описує модель Мейкірха як «не тільки таку, що об'єднує теоретичну основу для здоров'я та хвороб, а й створює «ешафот» для сучасної медицини і суспільної охорони здоров'я». В своій основі ця модель розглядає здоров'я як здатність людини задовольняти життєві потреби в контексті його соціальних і екологічних умов. Кожен індивід отримує «дар» «біологічно даного потенціалу» при народженні. Наш генетичний склад і час, проведений в утробі матері, можуть позитивно або негативно вплинути на людський потенціал. Після народження наш біологічно даний потенціал кінцевий і з часом зменшується аж до нашої смерті.

У 1982 році Стоукс, Норен і Сінделл визначили здоров'я як «стан, що характеризується анатомічною, фізіологічною та психологічною цілісністю; здатністю виконувати особисті, сімейні, робочі та громадські ролі; здатністю справлятися з фізичним, біологічним, психологічним і соціальним стресом» [51]. Важливо, що це визначення неявно вводить поняття стійкості як засіб подолання стресу, що відчуває індивід.

Серед десятків інших підходів звернемо увагу на дефініцію Г. Л. Апанасенка та Л. О. Попової, в якій здоров'я визначається як «гармонія, внутрішньо системний порядок, що забезпечує такий рівень енергетичного потенціалу, який дозволяє людині добре почуватися й оптимально виконувати біологічні та соціальні функції». Інтерес представляє внесення в дефініцію логіки системного порядку, але присутні перелічені вище 
недоліки - відсутність метрики, розуміння зв'язку людини та навколишнього середовища тощо [3-5].

3 точки зору Р. М. Баєвського здоров'я - це «контрольований специфічний стан людського організму, що забезпечує досягнення ним свого функціонального оптимуму. Це можливість організму людини адаптуватися до змін навколишнього середовища, взаємодіючи з ним вільно, на основі біохімічної, психологічної та соціальної сутності людини». Тут використано поняття взаємодії людини та навколишнього середовища, додано «біохімічної, психологічної та соціальної сутності людини», але, як і раніше, немає логіки вимірів, ресурсу здоров'я $[5,9]$.

В низці досліджень $[7,8,19,20,30,34,35,44$, $55,58]$ здоров'я людини визначається «як єдність безлічі обмінних процесів між організмом і навколишнім середовищем», характеризуючи здоров'я через стан адаптаційних процесів, що відображають різні ступені адаптації тієї чи іншої системи організму, через рівень функціональних можливостей організму, діапазон його компенсаторноадаптаційних реакцій в екстремальних умовах, через стан гармонічної саморегуляції та динамічної рівноваги із середовищем, через психофізичний стан людини, що характеризується відсутністю патологічних змін і функціональним резервом, достатнім для повноцінної біосоціальної адаптації, збереження фізичної та психічної працездатності в умовах природного місця існування». Важливими доповненнями порівняно з переліченими дефініціями слід вважати: стан гармонійної саморегуляції і динамічної рівноваги із середовищем, поняття «в умовах природного місця існування», принципу визначення «стану людини, що характеризується відсутністю патологічних змін і функціональним резервом, достатнім для повноцінної біосоціальної адаптації». У той же час, немає явного розуміння досягнення динімічної рівноваги 3 навколишнім середовищем не зважаючи на його величину, немає логіки кількісного визначення порогів адаптації, відсутнє визначення «патологічних змін» тощо.

Останнім часом фінансова складова забезпечення медичної допомоги вийшла на перший план, конкуренція в нинішній системі охорони здоров'я не прирівнюється до цінності для пацієнта, тому що

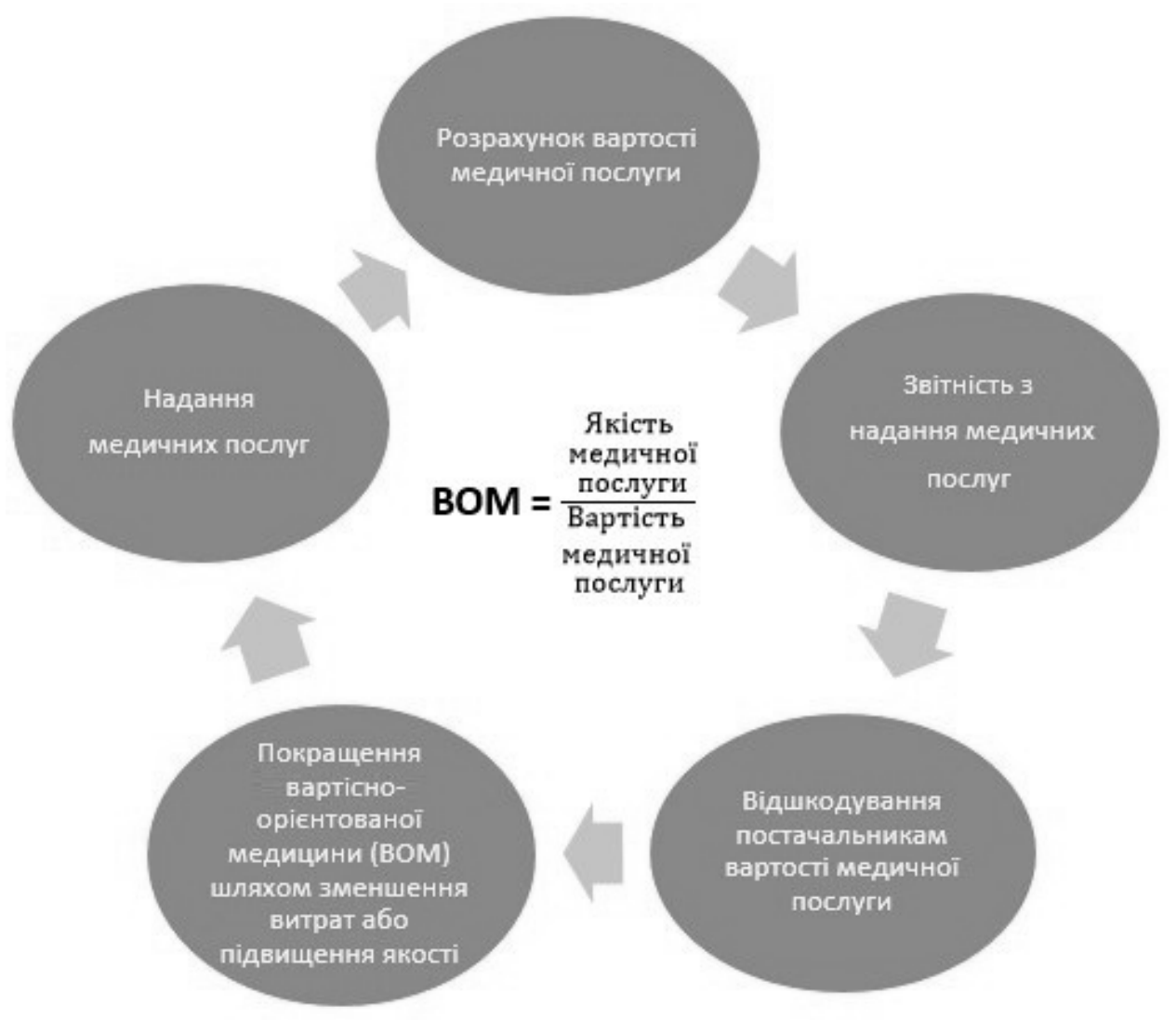

Рис. 1. Модель вартісно-орієнтованої медицини 
фінансовий успіх для постачальників послуг не прирівнюється до успіху, пов'язаного зі здоров'ям пацієнта. В наслідку виникла думка, що охорона здоров'я має грунтуватися на фінансовій основі, яка визначається як результати здоров'я, досягнуті в розрахунку на витрачені гроші $[14,18,50$, 57]. Така вартісна система закріплює зв'язок між відшкодуванням, вартістю послуг і досягненням результатів здоров'я, що оцінюються пацієнтами (рис. 1).

Porter M. вважає, що ефективна система охорони здоров’я, заснована на вартості, повинна спиратися на шість різних принципів [14]: 1) організація інтегрованих практичних підрозділів (ІПП), що забезпечують повний цикл надання медичної допомоги при даному стані пацієнта; 2) визначення витрат і результатів для кожного пацієнта; 3) перехід до комплексних платежів, що охоплює повний цикл догляду за гострими захворюваннями, загальний догляд за хронічними захворюваннями протягом заздалегідь визначеного періоду; 4) інтеграція надання медичної допомоги в окремих установах шляхом призначення одного лікаря-лідера для кожного пацієнта та прийняття загальних протоколів; 5) територіальне розширення охоплення медичних установ за рахунок використання супутникових локацій; 6) підтримка цих змін за допомогою платформи медичних інформаційних технологій (IT), що орієнтована на пацієнта та $є$ універсальною, спрощує управління медичними даними і доступна всім медичним працівникам. У результаті можливий перехід до пакетних платежів таким чином, щоб поєднати відшкодування загального догляду за пацієнтом із конкретним захворюванням. Подібні намагання прив'язати визначення здоров'я до надання послуг призводять до зміни дефініції здоров'я. Отже, встановлено критичну необхідність додавання до визначення ВООЗ принципів технологічного надання медичної допомоги, інфраструктурності системи охорони здоров'я, що зосереджена навколо пацієнтів.

Зауважимо, що таке визначення «здоров'я» підкреслює важливість задоволення всіх специфічних потреб пацієнта, які повинні охоплювати спектр медичної допомоги, включаючи лікування супутніх захворювань, ускладнень і пацієнт-унікальних обставин, а також профілактику майбутніх захворювань, але, на жаль, втрачається головне - логіка забезпечення саме здоров'я пацієнта.
Тому авторами зроблено спробу з урахуванням накопичених знань повернутися до основної проблеми - дефініції здоров'я.

Нова філософія індивідуального здоров'я. Запропоновано визначення здоров'я індивіда як «забезпечення квазістаціонарності фізіологічних, біологічних, психічних, соціальних, інтелектуальних і моральних характеристик людини при не екстремальних впливах навколишнього середовища на індивіда».

Подібна дефініція вимагає більш чіткого розуміння стаціонарності та квазістаціонарності. Під стаціонарністю розуміли властивість процесу не змінювати з часом свої характеристики. Іншими словами, стаціонарними вважали процеси, що не залежать від визначеного часу спостережень. Відповідно, квазістаціонарним процесом вважали такий, що наближається до стаціонарного. Зазвичай, застосовували його в тих випадках, коли характерний час встановлення рівноваги в біосистемі значно менше характерного часу існування рівноважності параметрів системи. Якщо визначати більш суворо: «квазістаціонарний процес відбувається в обмеженій системі та розповсюджується в ній так швидко, що за час поширення цього процесу в межах системи ії стан не встигає змінитися». Тому при розгляді процесу можна знехтувати часом його поширення в межах системи.

Подібне розуміння індивідуального здоров'я дало можливість сформулювати вісім принципів нової філософії здоров'я:

1. Індивідуальне здоров'я слід розглядати у взаємозв'язку з популяційним здоров'ям.

2. Оцінювання здоров'я людини та популяції повинно проводитися з урахуванням характеристик навколишнього середовища.

3. Невід'ємною частиною здоров'я індивіда $€$ його ресурс.

4. Здоров'я - це ряд стійких станів організму на різних рівнях, що визначаються особливостями зовнішніх збурюючи факторів і з’ єднуються адаптаційними перехідними процесами, які повинні бути кінцевими та визначеними в часі.

5. Найважливішими характеристиками здоров'я $€$ гармонійність змін, пропорційність їхньої динаміки.

6. Якщо здоров'я індивідуума визначається багато в чому здоров'ям популяції, то здоров'я 
популяції не є сумою здоров’я індивідуумів. Здоров’я популяції - інтегральна характеристика, при оцінюванні якої слід ураховувати кумулятивні властивості більшості складових.

7. Для кожної людини існує максимально високий рівень здоров'я та оптимальний (за обраним критерієм) шлях його досягнення.

8. Оцінювання здоров'я індивіда не може бути здійснено лише на основі статичних показників. У його вимірі повинні бути присутніми тестові навантажувальні впливи, програми самоконтролю та самооцінювання.

Математично індивідуальне здоров'я можна оцінити як адитивну функцію показників стаціонарності та фізіологічних, біологічних, психічних і соціальних функцій індивіда. В цьому випадку під показником стаціонарності розуміється нормована дисперсія маніфестаційних показників.

Отже, індивідуальне здоров’я $X_{i}$ дорівнює:

$$
X_{i}=\sum_{i} \sum_{j} \sum_{k} \sum_{e} \frac{P_{i j k e}}{\bar{X}_{i j k e}},\left\{\begin{array}{c}
i \neq j \neq k \neq e \\
\mathrm{i}, \mathrm{j}, \mathrm{k}, \mathrm{e}=1,2,3 \ldots \mathrm{n}
\end{array}\right\}
$$

де і — мінливість фізіологічних функцій індивіда, j - мінливість біологічних функцій індивіда, $\mathrm{k}$ - мінливість психічних функцій індивіда, е мінливість соціальних функцій індивіда.

Інший шлях згортання інформації - цілеспрямований - має на меті наявність спеціально організованої процедури обсягів аналізованої інформації. Вона може бути отримана як результат експертного оцінювання, так і формалізовано. В будь-якому випадку, на основі сформульованих і кількісно обгрунтованих критеріїв здійснюється вибір або конструювання найбільш інформативних змінних - індексів стану. Останні є результуючим показником стану пацієнта або функціонування системи його корекції. Відповідно в більшості випадків параметри стану, що лежать у його основі, втрачають свою індивідуальність. А індекси стають маркерами системи, трасером траєкторій їі розвитку. Отже, стан системи завжди можна описати вектором (або кортежем, якщо враховуються також величини, що не мають чисельних значень) стану системи. В ряді досліджень подібний вектор називають «портретом» системи. Наш досвід свідчить про доцільність проведення процедури порівняння на основі зіставлення інтегральних оцінок «портретів» системи, встановлення значимості цього об'єкта в цілому або окремих його властивостей на основі їхньої відповідності певним рівням або нормам.

Логіка гармонізації при визначенні здоров'я. Відповідно до визначення в розуміння гармонії вкладається конгруентне поєднання окремих частин у впорядковане ціле. В докуменах ВООЗ можна знайти поняття гармонії, коли життя сприймається як щось зрозуміле, кероване та наповнене сенсом, що складає величезний ресурс для здоров’ я людей [61]. Здоров’я зміцнюється, якщо люди впевнені та відчувають, що їх життя має сенс і що вони володіють достатнім вмінням і можливостями (розумовими, фізичними, емоційними, соціальними та матеріальними), для того щоб відповідати будьяким пропонованим до них вимогам.

Почуття гармонії має формуватися, починаючи 3 раннього дитинства. Політика, що має безпосередній вплив на молодих людей, а також на умови, в яких вони навчаються, працюють, живуть або проводять вільний час, повинна бути орієнтована на зміцнення цього почуття гармонії. Має бути гармонізована й система спостереження за поведінковими чинниками ризику шляхом активації повторних обстежень. Вимірювати слід поведінку, що, як відомо, викликає хвороби або травми (наприклад, вживання тютюну чи алкоголю, незахищений секс або відсутність фізичних вправ). Оскільки метою багатьох стратегій програм втручання являється профілактика захворювань шляхом запобігання нездорової поведінки, такі обстеження дозволяють безпосередньо оцінити вплив на людину, часто задовго до можливих наслідків для здоров'я. Проте спостерігання за показниками функционального статусу людини, як і аналіз факторів ризику, наштовхується на неймовірні обсяги інформації, що потребують її стиснення.

Синдромний нагляд. Під синдромом, зазвичай, розуміють сукупність симптомів із загальною етіологією та єдиним патогенезом. У широкому сенсі синдром - комплекс органічно пов'язаних між собою ознак, об'єднаних єдиним механізмом виникнення та розвитку даного явища, що не обов’язково пов'язане з патологією (захворюванням) [63]. Поняття синдрому введено ще Авіценною в «Каноні медицини», який вперше запропонував ідею синдрому в діагностиці конкретних захворювань. 
Для нас важливою характерною рисою синдрому є те, що він може бути наслідком впливу на організм різних причин і факторів, оскільки організм часто відповідає кінцевою кількістю загальних типових реакцій. Це дозволяє суттєво зменшити обсяги інформації, для визначення стану доров'я.

В практичній медицині часто використовується таке розуміння синдрому - це активна чи пасивна система, що використовує визначення стану здоров'я або захворювання, повністю засновані на клінічних ознаках без будь-якого лабораторного висновку. Оскільки синдромний епіднагляд $є$ недорогим і швидшим, ніж системи, що вимагають лабораторного підтвердження, він часто $€$ першим видом епіднагляду. Однак через відсутність специфічних ознак для більшості станів синдроми потребують більш ретельного вивчення. Крім того, зростання одного захворювання, що викликає синдром, може маскувати розвиток іншого.

Серйозною проблемою при обгрунтуванні синдромів $€$ коморбідність патологічних станів, постійна зміна клінічної картини захворювань. Зрозуміло, що в меншій мірі це стосується формування синдромів, коли ми говоримо про індивідуальне здоров’я. Проте, взаємодія особистості 3 навколишнім середовищем, спосіб життя та інші фактори і конфаундери можуть зіграти суттєву роль у зміні складу синдрому. Більш того, обгрунтування синдромів для оцінювання індивідуального здоров'я можливе лише за умови досить тривалого моніторингу та періодичного постійного спостереження за пацієнтом для адекватної корекції. Проте в такому випадку виникає інша велика проблема, що саме необхідо моніторувати. Відповідь полягає в організації комплексного спостереження за пацієнтом.

Комплексне спостереження за станом здоров'я. Основним фактором, який стимулює розвиток індивідуального моніторингу здоров'я (Personal Health Monitoring - РНМ), являється швидке старіння населення планети, що, за прогнозами, збільшить навантаження на системи охорони здоров'я багатьох країн, потенційно випереджаючи наявні медичні ресурси $[43,49,53]$. Хоча літні люди - основна сила, котра стоїть за РНМ, проте наявний підвищений інтерес населення до проблем власного здоров’я обумовлює появу сотен досліджень з цього напряму.
Як зазначалось, складність рішень організації моніторингу здоров'я пацієнта обумовлені багатофакторністю та багатопараметричністю інформації при діагностиці його стану (дані анамнезу, показники лабораторних і інструментальних обстежень тощо). В клінічній ситуації від лікаря, особливо спеціаліста в конкретній області, потрібен професійний підхід до виконання діагностичних і лікувальних процедур, уміння якісно систематизувати множини даних, отриманих у результаті лікування. Ефективність комплексного спостереження в цьому випадку в більшій мірі залежить від технології збору, накопичення даних і способів їх оброблення. Оптимальне поєднання медичних інформаційних систем, що використовують єдину інфраструктуру для збору інформації про різні захворювання на базі закладу охорони здоров'я дійсно може забезпечити необхідні дані для прийняття рішень відносно стану пацієнтів.

Розроблені технології раннього попередження базуються на єдиному контрольному показнику, що попереджає медичних працівників, якщо у пацієнта проявляються погіршення стану. Отже, лікарі можуть швидко підключатися та вчасно запобігати розвитку ускладнень. Така технологія може бути адаптована до конкретних потреб пацієнта. Наприклад, у палатах інтенсивного догляду за пацієнтами з COVID-19 у комплексному спостереженні оцінюються ключові показники, такі як рівень кисню в крові.

Ще один спосіб комплексного спостереження використання інноваційних практик віддаленого моніторингу. Пацієнти спостерігаються дистанційно 3 централізованого віртуального центру медичної допомоги. Подібні комплекси (на відміну від клінічного моніторингу) в більшій ступені фіксовані за комплексом технічного забезпечення, але мають широкі можливості по тестовим факторам (обсяги та характер навантаження, а також режими відпочинку).

В оцінюванні індивідуального здоров'я комплексне спостереження найчастіше використовується лише на першому етапі для визначення так званих індикаторів здоров'я.

Індикатори в оцінюванні індивідуального здоров'я. Відповідно до визначення індикатор - це параметр контрольованого процесу або стану об’єкта в формі, найбільш зручної для 
безпосереднього сприйняття людиною візуально, акустично, тактильно або іншим способом, що легко інтерпретується. Тобто індикатор являє собою фактор, що можна вимяряти та дозволяє об’єктивно оцінити розмір проблеми зі здоров'ям і контролювати фізіологічні процеси в індивіда.

Дуже часто визначення стану здоров'я пацієнта за одним показником може виявитися (чи здаватися) недостатнім. Тоді найбільш прийнятним методом вимірювання індивідуального здоров'я $\epsilon$ бальне оцінювання, що дозволяє отримувати інтегральні (композитні) індикатори стану людини. Однак, слід зауважити, що проблемною областю являється зважування окремих показників, що впливають на композити. Вибір ваг для окремих показників - ключовий фактор, що визначає ефективність індикатору. Тому необхідна певна обгрунтованість їх важливості, що надається кожному виміру з точки зору мети показника, з підкріпленням фактичними даними. На жаль, у багатьох випадках схеми не дають явного обгрунтування ваг, що використовуються для створення композиту.

Сучасні методи візуалізації даних можуть допомогти зробити складові показники більш інформативними та корисними в охороні здоров'я, можливо, спираючись на те, що з'являються приклади складових показників і рейтингів за межами конкретної ситуації, де користувач може інтерактивно вказати вагові коефіцієнти та побачити вплив на результати. Останнє може дозволити користувачам створювати композити, що відображають їх власні пріоритети, та досліджувати невизначеність через спосіб агрегування показників [21]. Проте погано спроєктована візуалізація може ввести користувачів в оману чи потребувати більше зусиль для розуміння, ніж менш привабливі варіанти. Дослідження, зосереджене на розробленні проєктів, переваги та шкода різних стратегій візуалізації даних для вимірювання продуктивності, мають життєво важливе значення.

Помітний вплив на індикаторне уявлення спостереження за здоров'ям здійснює медикалізація. Термін «медикалізація» часто застосовують у негативному сенсі, проте у медикалізації є і позитивна сторона: медикалізація може бути корисним i необхідним процесом у тих випадках, коли баланс користі та шкоди дотриманий. Хоча цей термін досить рідко використовувався в якості фактора (чи конфаундинга), проблеми, що він породжує досить значні. В контексті моніторингу особистого здоров’я, медикалізація означає, що пристрої повинні нагадувати користувачу або особі, які знаходяться в медичному стані в немедичному середовищі про додаткові ризики при зміні базових значень показників, що реєструються. Саме такий ризик «незрозумілої» з точки зору пацієнта дінаміки показників стану не дозволяє користувачу уникнути думки, що здіснюється «моніторинг заради моніторингу».

В цьому сенсі існує ризик для розробників гаджетів РНМ-технологій стосовно оцінювання отриманих даних (ефективності, пертинентності тощо) в плані вдосконалення приладів.

На закінчення даного розділу відмітимо, що слід розрізняти здоров'я індивіда та потенціал здоров'я. Останній може розглядатися як певний «абсолют» здоров'я, що характеризується біологічним максимумом, який знижується протягом життєвого циклу в результаті впливу патологічних станів людини. Стосовно головного індикатору здоров'я людської популяції — це в більшості рекомендацій визнається як очікувана тривалість майбутнього життя, що обчислюється на основі смертності поколінь за роками.

Активний нагляд за станом індивідуального здоров'я. В більшості досліджень подібний нагляд здійснюється за допомогою системи, в якій індивід забезпечує регулярне спостереження за власним здоров'ям і при необхідності здійснює консультування 3 лікарями для отримання інформації про стан, корекцію та підтримку здоров'я. Ще раз підкреслимо, що активне спостереження дає найточнішу та своєчасну інформацію.

В той же час нагляд за здоров'ям - це постійний систематичний збір, аналіз і інтерпретація даних, тісно пов'язаних зі своєчасним їх передаванням лікарю, який відповідає за профілактику та контроль захворювань.

Активний нагляд породжує низку досить складних проблем. Цілі та обмеження складових інтегральних показників повинні бути представлені разом із їх оцінками для розуміння звідки беруться оцінки, що вони означають і що обмежує їх корисність або інтерпретованість. Вважається, що методологічна інформація повинна бути легкодоступною, чітко пов'язаною з показником і логічною. 
Важливим елементом прозорості є представлення складових показників із супутніми проявами статистичної невизначеності. Невизначеність у складових показниках виникає як через статистичний шум, так і внаслідок способу вибору, стандартизації та агрегування окремих показників. Інтервальні оцінки та довірчі інтервали $є$ типовими представниками невизначеності. Ще один критичний показник - чутливість. Аналіз чутливості повинен показати, чи існують розумні альтернативні методи істотно змінити організаційні ранжування.

Однією з альтернатив може бути побудова формальної моделі прийняття рішень, заснованої на визначенні шкоди пацієнту, але на практиці це може викликати додаткові проблеми, пов'язані з тим, як оцінюється шкода.

При аналізі здоров'я простежується тенденція недооцінювання біологічних особливостей організму, в тому числі конституційних, хоча накопичено багато даних про істотний вплив індивідуальнотипологічних особливостей организму на різні боки здоров'я.

Для моніторингу прогресу у покращанні надання медичних послуг необхідно обгрунтувати метрику цього прогресу, ключові характеристики належного надання послуг у системі охорони здоров'я. Подібні характеристики, вочевидь, залежать від конструкції системи охорони здоров'я. Враховуючи рекомендації ВООЗ відносно сильної системи охорони здоров'я, що заснована на первинній медичній допомозі, можливо запропонувати «ідеальні» характеристики, що віддзеркалюють якість процесів раннього виявлення захворювань, кількість ускладнень, рівень залученності спеціалістів кваліфікованної та спеціалізованної медичної допомоги. Зрозуміло також, що процес збирання доказів для посилення надання медичних послуг повинен тривати поряд із зусиллями з реструктуризації надання послуг відповідно до появи нових технологій діагностики та лікування.

Підкреслимо, що низка понять, які часто використовувались раніше для вимірювання медичних послуг, залишаються надзвичайно актуальними й сьогодні. Наприклад, такі поняття, як доступ до надання медичної допомоги, іï доступність, рівень охоплення населення певними процедурами тощо.

Управління власним здоров'ям. Управління власним здоров'ям - комплекс механізмів, що спонукають людину прийняти рішення управляти своїм здоров'ям [12]. Відповідно до цього визначення, методи управління здоров'ям будемо класифікувати так:

- орієнтовані на підвищення мотивації управляти своїм здоров'ям: пропаганда здорового способу життя, змінення ставлення до свого здоров'я, створення сприятливої атмосфери в закладах охорони здоров'я для підтримки бажання управляти своїм здоров'ям;

- орієнтовані на організацію процесу управління власним здоров'ям. У свою чергу, вони базуються на системі орієнтації (принципах прийняття рішень), а також на можливості використаня валідних та якісніх методик надання коригуючої медичної допомоги. Остання має грунтуватися на сучасних медичних технологіях діагностичних, профілактичних і реабілітаційних послуг, безпека й ефективність яких підтверджена принципами доказової медицини.

Серед технологій прийняття рішень останнім часом запропоновано використання комунікаторів, систем домашньої мобільної медицини та мобільної медицини [15, 17, 39].

Важливим ресурсом в екосистемі здоров'я стали смартфони. Інтерес до застосування персональних технологій для догляду за собою постійно зростає. 3'явилися мобільні пристрої, такі як бездротові манжети для вимірювання кров'яного тиску або частоти серцевих скорочень, що зможуть допомогти пацієнтам ставити конкретні цілі, відслідковувати прогрес і відстежувати характер вправ, а також відправляти цю інформацію безпосередньо своєму лікареві через веб-сайти або додатки. Але виникають і нові проблеми, повязані з розумінням даного питання користувачами послуг, наприклад, скільки з них насправді діляться даними з лікарями, як вони інтегрують ці дані осмисленим чином, чи забезпечена сумісність різних гаджетів? Надзвичайно важливими стали питання інформаційної асиметрії, на які досі немає однієї відповіді. В той же час, нові гаджети та додатки з'являються на ринку з фантастичною швидкістю. Це означає, що вкрай необхідно розробити більш чіткий шлях для з'єднання технологій із цифровими перетвореннями. Результатом стане повне переосмислення того, як має здійснюватися охорона здоров’я. 
Загальний суспільний напрям на цифровізацію перекреслює й сумніви відносно того, що мобільне відстеження дозволить поліпшити управління особистим здоров'ям. Починаючи з телемедицини (послуги phone-a-doc), використання фітнес-трекерів у стимулюванні фізичної активності, закінчуючи програмами електронної охорони здоров'я та іншими технологіями філософія нової медицини забезпечує очевидну користь у сенсі зниження ризиків виникнення захворювань.

Однак, залишаються головні питання - вибір валідного та релевантого індикатора і кількісне оцінювання стану здоров'я.

Концептуальні погляди на проблему кількісного оцінювання здоров'я. Взагалі, для кількісного оцінювання здоров'я використовують різні підходи та класифікації. Виділяють ізольовані (прямі та непрямі), комплексні, багатокритеріальні, інтегральні оцінки. Зрозуміло, що для практичних завдань найбільший інтерес представляє саме остання. Під інтегральним оцінюванням стану пацієнта розуміється таке параметрічне визначення характеристик пацієнта, що забезпечує адекватне параметрам навколишнього середовища та внутрішнім критеріям функціонування організму. В цьому визначенні залишаються розмитими поняття «адекватності» та «внутрішні критерії функціонування організму». Але більш релевантних дефініцій у літературі знайти важко.

Вже згадані роботи Г. Л. Апанасенка, в яких запропоновано концепцію здоров'я індивіда, відповідно до якої «існує якийсь обумовлений еволюцією поріг енергопотенціалу біосистеми, вище якого в індивідів практично не реєструються ні ендогенні фактори ризику, ні хронічні соматичні захворювання. Він позначений як «безпечний рівень» соматичного здоров'я індивіда та характеризується максимальними можливостями аеробного енергоутворення 40-42 мл/кг/хв (11-12 МЕТ) для чоловіків і 33-35 мл/кг/хв (10-11 МЕТ) для жінок, знаходиться між III-IV рівнями соматичного здоров'я (12 балів за шкалою експрес-оцінювання). Нижче цього порога соматичного здоров'я індивіда розвиваються спочатку ендогенні фактори ризику, а при подальшому зниженні - хронічні соматичні захворювання, зростає ризик смерті. Цей поріг кількісно охарактеризований за показниками максимальної аеробної здатності, що дозволяє при відповідних заходах виключити сам ризик виникнення захворювань» [4]. Продовжуючи цю думку автор пише «Отже, основна умова існування всього живого на Землі - можливість поглинати енергію з зовнішнього середовища, акумулювати iї та використовувати для здійснення процесів життедіяльності. Чим більш доступними для використання резерви біоенергетики, тим організм життєздатныший, бо життя підтримується тратою енергії ... проблема вимірювання ступеня життєздатності (читайте - рівня соматичного здоров'я) впирається в проблему вимірювання максимального споживання кисню». Постійно дискутуючи 3 автором ми неодноразово підкреслювали, що поняття «енергії» у певній мірі є умовною величиною. Нам представляється, що використання енергетичних підходів для обгрунтування норми не зовсім коректно. Звернемося до класичного вислову нобелівського лауреата Р. Фейнмана щодо енергії «... існує певна величина, що називається енергія, яка не змінюється ні при яких перетвореннях, що відбуваються в природі. Само це твердження вельми і вельми абстрактно. Це, по суті, математичний принцип, що стверджує існування деякої чисельної величини, яка не змінюється ні за яких обставин. Це аж ніяк не опис механізму явища або чогось конкретного, просто - напросто відзначається та дивна обставина, що можна підрахувати якесь число ...» [64]. Тим не менш, концепція Г. Л. Апанасенка знайшла практичне впровадження.

В іншому дослідженні [65] висловлено ще одну цікаву думку: «Здоров'я людини є якісною характеристикою, що складається з набору кількісних параметрів: антропометричних (зріст, вага тощо); фізичних (частота пульсу, артеріальний тиск); біохімічних (вміст хімічних елементів в організмі, еритроцитів, лейкоцитів тощо); біологічних (склад кишкової флори; наявність біомаркерів)».

Часто замість кількісного оцінювання здоров'я використовують виникнення ризиків захворювання. Так у роботі [62] досліджується ризик, пов'язаний із впливом на організм людини поліциклічних ароматичних вуглеводів. Кількісно визначається інкрементний довічний ризик розвитку раку, що моделюється на основі факторів дорожнього руху та землекористування. Інтегруючи всі виконані дослідження та реальні характеристики 
навколишнього середовища можливо створити матрицю визначення прогнозу стану здоров’я індивіда на основі існуючих ризиків.

Отже, дослідник використовує безліч нечітких понять для оцінювання та порівняння фізичних станів людини на наближеному, якісному рівні. Але якісне оцінювання не має властивості аддитивності, властиве звичним для нас числам, перш за все, тому, що якісне оцінювання сильно залежить від особи, яка приймає рішення, контексту та змісту, що вкладається в конкретному випадку. Формалізація таких оцінок може грунтуватися на теорії нечітких множин. Функція приналежності повинна бути задана поза самої теорії нечіткої математики й, отже, її адекватність не може бути перевірена засобами безпосередньо самої теорії. Це заважає застосуванню нечіткої теорії множин для вирішення прикладних завдань. Виходячи з природи суб'єктивних оцінок, побудова функції може виконуватися лише за експертним оцінюванням (експерта називають також особою, яка приймає рішення ОПР).

Виділяють дві групи методів побудови - прямі та непрямі. Прямі визначаються тим, що ОПР безпосередньо задає правила визначення величини функції приналежності. Вони використовуються для опису понять, що характеризуються вимірюваними параметрами та в яких шанс помилок і спотворень незначний. Група включає в себе частотний метод, метод парних співвідношень.

У непрямих методах експертна інформація $\epsilon$ тільки вихідною для подальшої обробки, значення функції вибираються таким чином, щоб задовольнити заздалегідь сформульованим умовам, наприклад, на основі стандартного набору графіків.

В основу визначення значущості (важливості, інформативності) покладено уявлення про складну систему, стан якої описується системою вихідних критеріїв. Прикладами таких багатопараметричних систем можуть служити природні утворення різного масштабу (в тому числі, такі, що характеризуються неаддитивними властивостями); природні та штучні екологічні системи, оцінюваною властивістю може виявитися якість середовища, продуктивність системи, їі стійкість до зміни параметрів режимів тощо. При цьому вихідні характеристики, що визначають рівень оцінюваної властивості, можуть бути вельми численні (число їх часто доходить до багатьох десятків найменувань) та створювати вельми складні системи, структуровані безліччю функціональних і кореляційних взаємозв’язків.

Метод інтегрального оцінювання кластерів показників, якості стійкості та благополуччя навколишнього середовища може знайти широке застосування в моніторингових дослідженнях. Слід звернути увагу на те, що в даному підході параметри та рівні оцінювання, оціночні шкали, алфавіти класів, пріоритети не закріплені жорстко. Це дозволяє модифікувати класифікації з використанням нових критеріїв і додаткової експертної інформації, створювати нові моделі класифікації оцінюваних систем і їх властивостей.

Оціночний алгоритм дозволяє: використовувати різнорідну інформацію щодо діапазону можливого варіювання значень вагових коефіцієнтів (умови неповної та неточної інформації); використовувати нечислову інформацію про порівняльну вагомість окремих показників, що виражається судженнями типу «більше - менше - однакове» тощо.

Сам процес побудови інтегральних критеріїв досить багатогранний. 3 одного боку, це обумовлено недостатністю вихідних даних і недостатністю розроблених процедур і правил нормування та обліку виду зв’язків (пряма, зворотна, лінійна, нелінійна) або відсутністю методик і правил для формування інтегральних критеріїв. 3 іншого боку, різнопланова агрегація показників обумовлює наявність декількох рівнів узагальнення та згортання показників, для яких також необхідно розробляти правила їх обліку (беручи до уваги їх різномасштабність).

Необхідність застосування інтегрального індексного показника була вирішена за рахунок введення в методику вагових коефіцієнтів, що визначаються з використанням методу рандомізованих зведених показників.

Поняття «норма» для індивідуального здоров'я. Досить велика група авторів вважає, що при кількісному оцінюванні індивідуального здоров’я саме поняття «норми» втрачає сенс, оскільки якщо воно відображає середньостатистичну величину, то не може бути прийнято за вихідну позицію, а розглядається як середня та досить умовна величина. При такому підході не враховуються індивідуальні гено- та фенотипічні особливості людини. Тому 
автори вважають за доцільне говорити про рівень здоров’я індивіда, який не повинен порівнюватися 3 рівнем здоров'я інших людей, а розглядатися в динаміці відносно вихідних для даного етапу обстеження результатів конкретної людини.

Однак, у більшій частині досліджень підкреслюється, що для стану організму людини існує поняття «норми». Згадаємо зокрема детермінанти здоров’я [65].

Також поширюється думка про наявність сталих станів організму. Вибір і обгрунтування критеріїв оцінювання сталості тимчасових станів пацієнтів грунтується на даних про найважливіші фактори ризику та конфаундери, характерні для досліджуваної патології чи кластеру реабілітації. Підкреслимо, що аналіз статистичних матеріалів дозволяє зробити висновок про те, що серед фізичних факторів найбільше значення має невиправдане фізичне навантаження, а серед фармацевтичних - необгрунтоване поєднання різних засобів, чи їх дозування.

Умови функціонування систем характеризуються «нормою» на основі системи критеріїв, що дозволяють виділити їх кордони, та «нормальними» впливами — відхиленням умов середовища від норми, що не викликає розвитку незворотних змін і не виводить системи за межі їх сталого стану чи умовної норми. Оцінювання стану пацієнта 3 цих позицій є співвіднесенням її властивостей із нормою (нормами) за величинами інтегральних показників стану.

Технічні засоби моніторингу особистого здоров'я. Діагностика станів людини серйозно недооцінюється в усьому світі. Зокрема, в 2015 році американська Національна академія медицини повідомила, що принаймні 5 \% амбулаторних пацієнтів у США неправильно діагностуються, від 6 \% до 17 \% несприятливих подій у лікарнях є результатом діагностичних помилок, крім того, такі помилки є причиною 10 \% усіх смертей пацієнтів $[13,32]$. Більш того, не дивлячись на важливість діагностики, цей напрям отримує мінімальне фінансування.

Лише в останні роки виокремився самостійний напрям - моніторинг особистого здоров'я (МоO3). Як нову технологію, їі можливо описати набором технічних засобів та алгоритмів прийняття рішень. Більшість із них ще зараз перебувають у розробленні та обмеженому використанні, але всі вони покликані доповнити алгоритми існуючої медичної допомоги. Програми розробляються майже для кожного вікового діапозону, причому багато з них націлені на забезпечення здоров’я людей похилого віку та хронічно хворих.

Моніторинг здійснюється за допомогою прямих i непрямих методів дослідження. При використанні непрямих методів і тестів можливі помилки, пов'язані з так званими хибнопозитивними та хибнонегативними результатами, чим рідше зустрічається захворювання, тим більше шансів використати подібну помилкову інформацію.

Зауважимо, що моніторинг обумовив появу низки етичних проблем. Вони повязані з забезпечнням валідності отриманної інформації, чутливості, специфічності, збереження персоналізованих даних тощо. Вважаємо, що в основному вони пов’язані з когнитивними проблемами. Тому категорії, суперечки та етичні проблеми потребують спеціального навчання лікарів для підвищення обізнаності про потенціальні наслідки МоO3.

Важливо також зауважити, що загальновизнаної технології визначення МоOЗ ще не існує. Вельми часто користуються близкими поняттями, частково синонімічними, пов’язаними термінами. Використовуються терміни «телездоров’я та телеобслуговування», «допоміжні технології», «супутній інтелект і всюдисущі обчислення», «соматичне спостереження», «розумні будинки та допоміжне життя», «носимі датчики здоров’я».

Користуються також робочим визначенням MoO3, відповідно до якого МоОЗ означає використання будь-якого електронного пристрою або системи, що поздовжньо контролює та реєструє дані про різні аспекти здоров’я людини. Щоб кваліфікуватися як елемент МоОЗ, пристрій повинен мати можливість передавати дані лікарю, консультанту, іншим зацікавленим особам і бути придатним для використання не спеціалістом поза традиційним медичним середовищем (наприклад, лікарні). Програми МоO3 можуть також аналізувати дані на місці та виявляти закономірності та ненормальні показники.

Зрозуміло, що аналіз повного переліку пристроїв для МоO3 не входить до завдань цієї статі. Зазначимо лише, що спектр моніторів для прямого визначення показників здоров'я людини надзвичайно широкий і включає ремінці на 
зап'ястя та руки, «розумний» одяг, GPS-трекери та смарт-телефонні пристрої. GPS-трекери відстежують параметри здоров' я та події, такі як хода чи падіння. Мережі бездротових медичних датчиків складаються 3 пристроїв, що можна носити, здатних здійснювати фізіологічний моніторинг, аналіз на місці та автоматичні сповіщення, коли показники виходять за рамки нормальних параметрів. Параметри, що моніторуються, включають кисень крові, частоту серцевих скорочень та ЕКГ, пульсоксиметрію, плетизмографічний сигнал та артеріальний тиск. Нове програмне забезпечення може перетворити існуючі пристрої на $\mathrm{MoO}$, як показано, за допомогою додатків для смартфонів для моніторингу стану здоров'я, що можуть відстежувати фізичні вправи або рух та обмінюватися даними 3 медичними працівниками та іншими третіми сторонами.

«Мережі тіла» або датчики, що користувач вплітає, або текстиль, одягнений під одяг, можуть поєднуватися з програмами для смартфонів для забезпечення поздовжнього відстеження стану здоров'я [39, 48].

Широке застосування МоО3 надає певні перспективи людству в напряму профілактики, лікування, реабілітації. Технології МоО3 мають визначений діапазон цілей, таких як поздовжній моніторинг стану здоров'я, рання діагностика, відгуки про спосіб життя та виявлення аномальних параметрів здоров’я та критичних ситуацій.

\section{Література.}

1. Многокритериальная оценка экологического состояния и устойчивости геосистем на основе метода сводных показателей. V. Интегральная оценка экологического состояния и качества среды урбанизированных территорий / Александрова Л. В., Васильев В. Ю., Дмитриев В. В. и др. // Вестник С.-Петербургского университета. Серия «Геология и география». - 2000. - Вып. 4, № 34. C. 40-52.

2. Апанасенко Г. Л. О возможности количественной оценки здоровья человека / Апанасенко Г. Л. // Гигиена и санитария. - 1985. - № 6. - С. 55-58.

3. Апанасенко Г. Л. Эволюция биоэнергетики и здоровье человека / Апанасенко Г. Л. - Санкт-Петербург: МГП «Петрополис», 1992. - 68 с.
Висновки. Визначення, оцінювання та управляння персональним здоров’ям слід розцінювати сьогодні як найважливіші соціальні проблеми, що потребують невідкладного рішення.

1. Запропоновано нову концепцію визначення та оцінювання індивідуального та популяційного здоров’я, в основу якого покладено стаціонарність, дисперсійні характеристики критеріїв стану організму при неекстремальному впливі навколишнього середовища.

2. Для процесів медичної реабілітації запропонована концепція надає кількісний інструментарій лояльного оцінювання коректності обраного шляху відновлення здоров’я.

3. Запропоновано інтегральне оцінювання стану пацієнта, що може знайти широке застосування в моніторингових дослідженнях здоров’я пацієнта. В даному підході параметри та рівні оцінювання, оціночні шкали, алфавіти класів, а також пріоритети не мають суворого закріплення. Це дозволяє модифікувати класифікації з використанням нових критеріїв і додатковою експертною інформацією та створювати нові моделі-класифікації функціонального стану організму. Оціночний алгоритм дозволяє: використовувати різнорідну інформацію стосовно діапазонів можливого варіювання значень вагових коефіцієнтів (неточна інформація); використовувати нечислову інформацію стосовно порівняльної вагомості окремих показників, що виражається судженнями типу «більше - менше - однакове»; широко використовувати неповну информацію, коли значення деяких вагових коефіцієнтів не входять у заплановані діапазони.

4. Индивидуальное здоровье: теория и практика. Введение в теорию индивидуального здоровья / Апанасенко Г. Л., Попова Л. А. - К.: Медкнига, 2011. - 108 с.

5. Концепция здоровья и космическая медицина / Баевский Р. М., Григорьев А. И. - М.: Слово, 2007. 208 c.

6. Быков В. С. Формирование здорового стиля жизни у студенческой молодёжи / В. С. Быков // Физическая культура и здоровье студентов вузов: материалы $\mathrm{V}$ междунар. науч.-практ. конф. - СПб.: Изд-во СПбГУП, 2009. - С. 10-11.

7. Викторов Д. В. Анализ индивидуального здоровья по функциональным параметрам систем организма человека / Викторов Д. В. // Вестник ЮУрГУ. - 2011. № 7. - С. 15-18. 
8. Гаттаров Р. У. Психофизиологический потенциал и уровень здоровья студентов / Р. У. Гаттаров. - Челябинск: Изд-во ЮУрГУ, 2005. - 192 с.

9. Концепция здоровья и проблема нормы в космической медицине / Григорьев А. И., Баевский Р. М. - М.: Слово, 2001. - 92 с.

10. Дмитриев В. В. Интегральные оценки состояния сложных систем в природе и обществе / Дмитриев В. В. // Биосфера. - 2010. - Т. 2, № 4. - С. 507-520.

11. Исаев А. П. Информационные технологии в здравостроении, образовании и формировании современного человека / А. П. Исаев // Проблемы и перспективы здравостроения: сборник научных работ / под ред. А. П. Исаева. - Челябинск: Изд-во ЮУрГУ, 2000. - Вып. II. - С. 84-85.

12. Кулкаева Г. У. Методы управления собственным здоровьем / Кулкаева Г.У. // Международный научноисследовательский журнал. - 2015. - Т. 9, № 4 (40). С. 52-53.

13. Strategies to reduce diagnostic errors: a systematic review / Abimanyi-Ochom J., Mudiyanselage S. B., Catchpool M. et al. // BMC Medical Informatics and Decision Making. - 2019. - № 19, 174.

14. A strategy for health care reform: toward a value-based system / Porter M. E. // N Engl J Med. - 2009. - № 9. C. 109-112.

15. Acharya D. Security in Pervasive Health Care Networks: Current R\&D and Future Challenges / Acharya D. // Mobile Data Management (MDM): Eleventh International Conference On, 2010. P. 305-306.

16. A secure pervasive health care system using location dependent unicast key generation scheme / Acharya D., Kumar V. // 3rd Workshop on Ph.D. Students in Information and Knowledge Management, PIKM'10: Co-located with 19th International Conference on Information and Knowledge Management, CIKM'10. - Toronto, ON, 2010. - P. 87-90.

17. Medical biometrics in mobile health monitoring / Agrafioti F., Bui F. M., Hatzinakos D. // Security and Communication Networks. - 2011. - № 4. - P. 525-539.

18. Making equity a value in value-based health care / Alberti P. M., Bonham A. C., Kirch D. G. // Acad Med. 2013. - Vol. 88. - P. 1619-1623.

19. Antonovsky A. The salutogenic model as a theory to guide health promotion / Antonovsky A. // Health Promot Int. - 1996. - № 11. - P. 11-18.

20. Redefining Health: The Evolution of Health Ideas from Antiquity to the Era of Value-Based Care / Badash I., Kleinman N. P., Barr S., Jang J., Rahman S., Wu B. W. // Cureus. - 2017. - № 9 (2). - e1018.

21. The problem with composite indicators / Barclay M., Dixon-Woods M., Lyratzopoulos G. // BMJ Quality \& Safety. - 2019. - № 28. - P. 338-344.
22. The future of health information technology in the patient-centered medical home / Bates D. W., Bitton A. // Health Aff (Millwood). - 2010. - № 29 (4). P. 614-621.

23. Defining health by addressing individual, social, and environmental determinants: New opportunities for health care and public health / Bircher J., Kuruvillas S. // J Public Health Policy. - 2014. - № 35 (3). - P. 363-386.

24. Bircher J. Driving Forward A Paradigm Shift in Healthcare: The Meikirch Model / Bircher J. // Biology, Health and Medicine. - Dec 21, 2020. - Режим доступу: https://www.scientia.global/dr-johannes-bircherdriving-forward-a-paradigm-shift-in-healthcare-themeikirch-model/.

25. Bircher J. Towards a dynamic definition of health and disease / Bircher J. // Medicine, Healthcare and Philosophy. - 2005. - № 8. - P. 3335-3341.

26. Ethical Implications of Lifestyle Monitoring Data in Ageing Research / Bowes A., Dawson A., Bell D. // Information, Communication \& Society. - 2011. Vol. 15. - P. 5-22.

27. End-User perception towards pervasive cardiac healthcare services: Benefits, acceptance, adoption, risks, security, privacy and trust / Dhukaram A. V., Baber C., Elloumi L. et all // 5th International Conference on Pervasive Computing Technologies for Healthcare and Workshops, PervasiveHealth 2011. Dublin. - P. 478-484.

28. Sensor technology for smart homes / Ding D., Cooper R. A., Pasquina P. F., Fici-Pasquina, L. // Maturitas. 2011. - № 69. - P. 131-136.

29. Donev D. Human health - definition, concept and content. How the disease occurs and the natural course of disease. Modern concept and definition of healthcare / Donev D. / Nikodijevic B., editor. - Contemporary diagnostics and therapy in medicine. - Skopje: Faculty of Medicine, 2000. - P. 5-19.

30. Donev D. Toward the fourth dimension of health - the spiritual health / Donev D. // Vox Medici. - 2014. № 23. - P. 318-321.

31. Elsevier. Dorland's Illustrated Medical Dictionary (англ.). - Режим доступу: https://www.dorlandsonline. com/dorland/home.

32. Graber M. L. The incidence of diagnostic error in medicine / Graber M. L. // BMJ Qual Saf. - 2013. № 22 (Suppl 2). - P. 21-27.

33. How should we define health? / Huber M., Knottnerus J. A., Green L. et al. // BMJ (Clinical research ed). - 2011.№ 343. - P. 41-63.

34. Huber M. Invitational Conference "Is health a state or an ability» Towards a dynamic concept of health? / Huber M. // Report of the meeting, 2009. Dec 10-11, Accessed 19th November 2017. 
35. How should health be defined? / Jadad A. R., O’Grady L. // BMJ (Clinical research ed). - 2008. - № 337. P. 2900.

36. Kujundžić Tiljak M. The 90th anniversary of Andrija Štampar School of Public Health / Kujundžić Tiljak M. // Croat Med J. - 2017. - № 58. - P. 330-331.

37. Lenn Evan Goodman. Islamic Humanism. - Yale: Oxford University Press, 2003. - P. 155.

38. Salutogenesis / Lindström B, Eriksson M. // J Epidemiol Community Health. - 2005. - № 59. - P. 440-442.

39. Wireless sensor networks for personal health monitoring / Milenkovia A., Otto C., Jovanov E. // Computer Communications. - 2006. - № 29. - P. 2521-2533.

40. Mittelstadt B. Personal Health Monitoring. - Technical Report, January, 2013. - Режим доступу: http:// responsible-innovation.org.uk/torrii/resourcedetail/1053.

41. Validity of composite end points in clinical trials / Montori V. M., Permanyer-Miralda G., FerreiraGonzález I. et al. // BMJ. - 2005. - № 330. - P. 594-596.

42. Ethical issues of personal health monitoring: a literature review / Mittelstadt B., Fairweather N. B., McBride N. et al. // ETHICOMP-2011, Conference Proceedings. Режим доступу: https://ora.ox.ac.uk/objects/ uuid:42750043-4286-4258-ac93-c6c7768855cd.

43. The Role of the Family Context in the Development of Emotion Regulation / Morris A. S., Silk J. S., Steinberg L., Myers S. S., Robinson L. R. // Social development. 2007. - № 16 (2). - P. 361-388.

44. Personal health management systems: applying the full power of software to improve the quality and efficiency of care / Neupert P., Mundie C. // Health Aff (Millwood). 2009. - № 28 (2). - P. 390-392.

45. Noack H. Concepts of health and health promotion / Noack H. - Copenhagen: WHO Regional Office for Europe, 1994.

46. Obama's precision medicine initiative / Terry S. F. // Genet Test Mol Biomarkers. - 2015. - № 19. P. 113-114.

47. Health: redefined / Oleribe O. O., Ukwedeh O., Burstow N. J. et al. // Pan Afr Med J. - 2018. - № 30. - P. 292.

48. Socioeconomic Disparities in Health Behaviors / Pampel F. C., Krueger P. M., Denney J. T. // Annual review of sociology. - 2010. - № 36. - P. 349-370.

49. Concept and principles in health promotion / Donev D., Pavleković G., Zaletel Kragelj L., editors // Health promotion and disease prevention. Stability Pact Forum for Public Health Cooperation in SEE. - Lage: Hans Jacobs Publishing Co, 2007. - P. 3-14.

50. Prognostics and Health Management (PHM) system requirements and validation / Ping $\mathrm{Xu}$, Zili Wang, Vue Li // Prognostics and System Health Management Conference, 2010. - P. 1-4.

51. Value-based health care delivery / Porter M. E. // Ann Surg. - 2008. - Vol. 248. - P. 503-509.

52. Feynman R. The Feynman Lectures on Physics / Feynman R. - СШA: Addison Wesley, 1964.
53. Rutter M. Psychological resilience and protective mechanisms / Rutter M.//Am J Orthopsychiatry.-1987.№ 57. - P. 316-331.

54. Setting value-based payment goals: HHS efforts to improve U.S. health care / Burwell S. M. // N Engl J Med. - 2015. - № 372. - P. 897-899.

55. Smith R. The end of disease and the beginning of health / Smith R. // BMJ blogs. - 09 November 2017. - Peжим доступу: https://blogs.bmj.com/bmj/2008/07/08/ richard-smith-the-end-of-disease-and-the-beginningof-health/.

56. Definition of terms and concepts applicable to clinical preventive medicine / Stokes J, Noren J, Shindell S. // Journal of community health. - 1982. - № 8 (1). P. 33-41.

57. Distortion, confusion, and impasses: could a public dialogue within Knowledge Landscapes contribute to better communication and understanding of innovative knowledge? / Svalastog A. L., Allgaier J., Martinelli L., Gajović S. // Croat Med J. - 2014. - № 55. - P. 54-60.

58. The Free Dictionary - Medical dictionary. Holistic health. - 2017. - Режим доступу: http://medicaldictionary. The free dictionary.com/holistic+health.

59. The strategy that will fix health care / Porter M. E., Lee T. H. - 2013. - Режим доступу: https://hbr.org/2013/10/ the-strategy-that-will-fix-health-care HBR.

60. Towards a dynamic definition of health and disease / Bircher J. // Med Health Care Philos. - 2005. - № 1. P. 335-341.

61. The new public health / Tulchinski T., Varavikova E. A. // 3rd ed. San Diego: Elsevier Academic Press, 2014. P. 884.

62. Value-based health care for chronic care: aligning outcomes measurement with the patient perspective / Ebbevi D., Forsberg H. H., Essén A., Ernestam S. // Qual Manag Health Care. - 2016. - № 25. - P. 203-212.

63. What is health? The ability to adapt // Lancet. - 2009. № 373 (9666). - P. 781.

64. WHO-definition of health must be enforced by national law: a debate / Habersack M., Luschin G. // BMC Med. 2013. - № 14. - P. 24.

65. World Health Organization. About World Health Organization. Constitution. - Режим доступу: http:// www.who.int/governance/eb/constitution/en/.

66. World Health Organization. World Health Report Executive Summary - achieving health for all. - Режим доступу: http://www.who.int/whr/1998/media_centre/ executive_summary6/en/.

67. Quantitative assessment of human health risk posed by polycyclic aromatic hydrocarbons in urban road dust / Yukun M., An Liu , Prasanna Egodawatta, McGree J. et al. // Science of The Total Environment. - 2017. Vol. 575. - P. 895-904.

68. Щуліпенко I. М. Пропедевтика внутрішньої медицини: Загальна семіотика і діагностика. Навч. Посібник / Щуліпенко I. М. - К. : Медицина, 2008. - 304 с. 


\section{References.}

1. Aleksandrova, L. V., Vasil'yev, V. Yu., Dmitriyev, V. V. i dr. (2000). Mnogokriterial'naya otsenka ekologicheskogo sostoyaniya i ustoychivosti geosistem na osnove metoda svodnykh pokazateley. V. Integral'naya otsenka ekologicheskogo sostoyaniya i kachestva sredy urbanizirovannykh territoriy. [Multi-criteria assessment of the ecological state and stability of geosystems based on the method of summary indicators. V. Integral assessment of the ecological state and quality of the environment of urbanized territories]. Vestnik S.-Peterburgskogo universiteta. Seriya "Geologiya i geografiya” (Bulletin of St. Petersburg University. Series "Geology and Geography”), 4(34), 40-52. [In Russian].

2. Apanasenko, H.L. (1985). O vozmozhnosty kolychestvennoi otsenky zdorovia cheloveka [On the possibility of quantitative assessment of human health] Hyhyena y sanytaryia (Hygiene and sanitation), 6, 55-58. [In Russian].

3. Apanasenko, H.L. (1992). Evoliutsyia byoenerhetyky y zdorove cheloveka. [Bioenergy evolution and human health] Sankt-Peterburh. MHP Petropolys. [In Russian].

4. Apanasenko, G.L., Popova, L.A. (2011). Individual'noe zdorov'e: teoriya i praktika. Vvedenie v teoriyu individual'nogo zdorov'ya. [Individual health: theory and practice. Introduction to the theory of individual health]. Medkniga. [In Russian].

5. Baevskij, R. M., Grigor'ev, A. I. (2007). Koncepciya zdorov'ya i kosmicheskaya medicina [Health and space medicine concept.].M.: Slovo. [In Russian].

6. Bykov, V. S. (2009). Formirovanie zdorovogo stilya zhizni u studencheskoj molodyozhi [Formation of a healthy lifestyle among student youth]. Fizicheskaya kul'tura i zdorov'e studentov vuzov: materialy V mezhdunar. nauch.-prakt. konf. — (SPb.: Izd-vo SPbGUP), 10-11. [In Russian].

7. Viktorov, D.V. (2011). Analiz individual'nogo zdorov'ya po funkcional'nym parametram sistem organizma cheloveka [Analysis of individual health by functional parameters of human body systems]- Vestnik YUUrGU, 7, 15-18. [In Russian].

8. Gattarov, R. U. (2005). Psihofiziologicheskij potencial i uroven' zdorov'ya studentov [Psychophysiological potential and health level of students] - CHelyabinsk: Izd-vo YUUrGU. [In Russian].

9. Grigor'ev, A. I., Baevskij, R. M. (2001). Koncepciya zdorov'ya i problema normy v kosmicheskoj medicine [The concept of health and the problem of norm in space medicine]. M.: Slovo. [In Russian].

10. Dmitriev, V. V. (2010). Integral'nye ocenki sostoyaniya slozhnyh sistem $\mathrm{v}$ prirode i obshchestve [Integral assessments of the state of complex systems in nature and society]. Biosfera. №4. URL: https://cyberleninka. ru/article/n/integralnye-otsenki-sostoyaniya-slozhnyhsistem-v-prirode-i-obschestve. [In Russian].
11. Isaev, A.P. (2000). Informacionnye tekhnologii v zdravostroenii, obrazovanii i formirovanii sovremennogo cheloveka [Information technology in health care, education and the formation of a modern person] Problemy i perspektivy zdravostroeniya: sbornik nauchnyh rabot (Problems and Prospects of Healthcare: Collection of Scientific Papers). CHelyabinsk: Izd-vo YUUrGU, II, 84-85. [In Russian].

12. Kulkaeva, G.U. (2015). Metody upravleniya sobstvennym zdorov'em [Methods for managing your own health]. Mezhdunarodnyj nauchno-issledovatel'skij zhurnal (International research journal), 9-4 (40), 52-53. [In Russian].

13. Abimanyi-Ochom, J., Mudiyanselage, Sh.,B., Catchpool, M., et al. (2019). Strategies to reduce diagnostic errors: a systematic review. BMC Medical Informatics and Decision Making, 174.

14. Porter, M.E., (2009). A strategy for health care reform: toward a value-based system.. N Engl J Med; 9, 109112.

15. Acharya, D. (2010). Security in Pervasive Health Care Networks: Current R\&D and Future Challenges, in: Mobile Data Management (MDM), Eleventh International Conference, 305- 306.

16. Acharya, D., Kumar, V. (2010). A secure pervasive health care system using location dependent unicast key generation scheme, in: 3rd Workshop on Ph.D. Students in Information and Knowledge Management, PIKM'10, Co-located with 19th International Conference on Information and Knowledge Management, CIKM'10. Toronto, ON, 87-90.

17. Agrafioti, F., Bui, F.M., Hatzinakos, D. (2011). Medical biometrics in mobile health monitoring. Security and Communication Networks, 4, 525-539.

18. Alberti, P.M., Bonham, A.C., Kirch, D.G. (2013). Making equity a value in value-based health care; Acad Med. Nov. Vol. 88, 1619-1623.

19. Antonovsky, A. (1996). The salutogenic model as a theory to guide health promotion. Health Promot Int., 11, 11-8.

20. Badash, I., Kleinman, N.P., Barr, S., Jang, J., Rahman, S, Wu, B.W. (2017). Redefining Health: The Evolution of Health Ideas from Antiquity to the Era of Value-Based Care. Cureus, 9(2), e1018. Published 2017 Feb 9.

21.Barclay, M., Dixon-Woods, M., Lyratzopoulos, G. The problem with composite indicators. BMJ Quality \& Safety, 28, 338-344.

22. Bates, D.W., Bitton, A. (2010). The future of health information technology in the patient-centered medical home. Health Aff (Millwood),29(4), 614-21.

23. Bircher, J., Kuruvillas, S. (2014). Defining health by addressing individual, social, and environmental determinants: New opportunities for health care and public health. J Public Health Policy, 35(3), 363-386. 
24. Bircher, J. (2020). Driving Forward A Paradigm Shift in Healthcare: The Meikirch Model. Biology, Health and Medicine.

25. Bircher, J. (2005). Towards a dynamic definition of health and disease. Medicine, Healthcare and Philosophy, 8 (3335-341).

26. Bowes, A., Dawson, A., Bell, D., 2011. Ethical Implications of Lifestyle Monitoring Data in Ageing Research. Information, Communication \& Society.

27. Dhukaram, A.V., Baber, C., Elloumi, L., Van Beijnum, B.J., De Stefanis, P. (2011). End-User perception towards pervasive cardiac healthcare services: Benefits, acceptance, adoption, risks, security, privacy and trust. 5th International Conference on Pervasive Computing Technologies for Healthcare and Workshops, PervasiveHealth, Dublin, 478-484.

28. Ding, D., Cooper, R.A., Pasquina, P.F., Fici-Pasquina, L. (2011). Sensor technology for smart homes. Maturitas, 69, 131-136.

29. Donev, D. (2000). Human health - definition, concept and content. How the disease occurs and the natural course of disease. Modern concept and definition of healthcare [In Macedonian]. Nikodijevic B, editor. Contemporary diagnostics and therapy in medicine. Skopje: Faculty of Medicine; 5-19.

30. Donev, D. (2014). Toward the fourth dimension of health the spiritual health. Vox Medici, 23, 318-21.

31. Elsevier. Dorland's Illustrated Medical Dictionary.

32. Graber, M.L. (2013). The incidence of diagnostic error in medicine. BMJ Qual Saf., 22(2), 21-7.

33. Huber, M., Knottnerus, J.A., Green, L., van der Horst, H., Jadad, A.R., Kromhout, D., et al. (2011). How should we define health? BMJ (Clinical research ed), 343:4163.

34. Huber, M. (2017). Invitational Conference "Is health a state or an ability» Towards a dynamic concept of health? Report of the meeting.

35. Jadad, A.R., O’Grady, L. (2008). How should health be defined? BMJ (Clinical research ed), 337:a2900.

36. Kujundžić, Tiljak, M. (2017). The 90th anniversary of Andrija Štampar School of Public Health. Croat Med J., 58, 330-331.

37. Goodman L., E. (2003). Islamic Humanism. Yale Oxford University Press, 155.

38. Lindström, B., Eriksson, M., Salutogenesis (2005). Epidemiol Community Health, 59, 440-442.

39. Milenkovia A., Otto C. \& Jovanov E. (2006). Wireless sensor networks for personal health monitoring. Computer Communications, 29, 2521-2533.

40. Mittelstadt, B. (2013). Personal Health Monitoring. Technical Report http://responsible-innovation.org.uk/ torrii/resource-detail/1053.

41. Montori, V.M. , Permanyer-Miralda, G., FerreiraGonzález, I. et al. (2005). Validity of composite end points in clinical trials. BMJ, 330, 594-596.
42. Mittelstadt, B., Fairweather, N.B., McBride, N., Shaw, M. (2011). Ethical Issues of Personal Health Monitoring: A Literature Review. ETHICOMP Conference Proceedings, ETHICOMP.

43. Morris, A.S., Silk, J.S., Steinberg, L., Myers, S.S, Robinson, L.R. (2007). The Role of the Family Context in the Development of Emotion Regulation. Social development (Oxford, England), 16(2), 361-388.

44. Neupert, P., Mundie, C. (2009). Personal health management systems: applying the full power of software to improve the quality and efficiency of care. Health Aff (Millwood). 28(2), 390-392.

45. Noack, H. (1994). Concepts of health and health promotion. Copenhagen: WHO Regional Office for Europe.

46. Obama's precision medicine initiative. (2015). Terry, SF. Genet Test Mol Biomarkers, 19, 113-114.

47. Oleribe, O.O., Ukwedeh, O., Burstow, N.J, et al. (2018). Health: redefined. Pan Afr Med J., 30, 292.

48. Pampel, F.C, Krueger, P.M, Denney, J.T. (2010). Socioeconomic Disparities in Health Behaviors. Annual review of sociology, 36, 349-370.

49. Pavleković, G., Donev, D., Zaletel, Kragelj, L. (2007). Concept and principles in health promotion. Health promotion and disease prevention. Stability Pact Forum for Public Health Cooperation in SEE. Lage: Hans Jacobs Publishing Co, 3-14.

50. Xu, P., Wang, Z., Li, V. (2010). Prognostics and Health Management (PHM) system requirements and validation. Prognostics and System Health Management Conference, 1-4.

51. Porter, M.E. (2008). Value-based health care delivery. Ann Surg. Vol. 248, 503-509.

52. Feynman R. (1964). The Feynman Lectures on Physics. - USA: Addison Wesley.

53. Rutter, M. (1987). Psychological resilience and protective mechanisms. Am J Orthopsychiatry, 57, 316-331.

54. Burwell, S.M. (2015). Setting value-based payment goals: HHS efforts to improve U.S. health care. $N$ Engl J Med., 372, 897-899.

55. Smith, R. (2017). Richard Smith: the end of disease and the beginning of health. Accessed 19th November 2017.

56. Stokes, J., Noren, J., Shindell, S. (1982). Definition of terms and concepts applicable to clinical preventive medicine. Journal of community health, 8(1), 33- 41.

57. Svalastog, A.L., Allgaier, J., Martinelli, L., Gajović, S. (2014). Distortion, confusion, and impasses: could a public dialogue within Knowledge Landscapes contribute to better communication and understanding of innovative knowledge? Croat Med J., 55, 54-60.

58. The Free Dictionary - Medical dictionary. (2017). Holistic health. Available at: http://medical-dictionary.

59. Porter, M.E., Lee, T.H. (2013). The strategy that will fix health care. HBR. 91,50-70. URL: https://hbr. org/2013/10/the-strategy-that-will-fix-health-care. 
60. Bircher, J. (2005). Towards a dynamic definition of health and disease. Med Health Care Philos., 1, 335341.

61. Tulchinski, T., Varavikova, E.A. (2014). The new public health. San Diego: Elsevier Academic Press, 884.

62. Ebbevi, D., Forsberg, H.H., Essén, A., Ernestam, S. (2016). Value-based health care for chronic care: aligning outcomes measurement with the patient perspective. Qual Manag Health Care, 25, 203-212.

63. What is health? The ability to adapt. (2009). Lancet (London, England, 373(9666), 781.

64. Habersack, M., Luschin, G. (2013). WHO-definition of health must be enforced by national law: a debate. BMC Med., 14, 24.
65. About World Health Organization. Constitution. (2017). World Health Organization. URL: http://www.who.int/ governance/eb/constitution/en/. Accessed: December 27, 2017.

66. World Health Report Executive Summary - achieving health for all. (2017). World Health Organization. URL: http://www.who.int/whr/1998/media_centre/ executive_summary6/en/.

67. Ma Yu, , Liu A., Egodawatta P. , McGree, J., et al. (2017). Quantitative assessment of human health risk posed by polycyclic aromatic hydrocarbons in urban road dust. Science of The Total Environment, Vol. 575, 895-904.

68. Shchulipenko, I. M. (2008). Propedevtyka vnutrishnoi medytsyny: Zahalna semiotyka i diahnostyka. Navch. posibnyk. K. : Medytsyna. [In Ukrainian]. 